\title{
MUHAMMADIYAH COVID-19 ISLAMIC BOARDING SCHOOL: A COMPLETE SELF-ISOLATION MODEL WITH NEUROSPRITUAL AND PSYCHOSOCIAL APPROACHES
}

\author{
Mohammad Jailani ${ }^{*}$, Suyadi ${ }^{2}$ \\ ${ }^{1}$ Universitas Ahmad Dablan Yogyakarta, Indonesia, email: mohammad2007052014@,webmail.uad.ac.id \\ ${ }^{1}$ Universitas Ahmad Dablan Yogyakarta, Indonesia, email:suyadi@fai.uad.ac.id \\ *Corresponding Authors

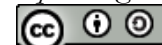 \\ (C)2021 by the authors. Submitted for possible open access publication under the terms and conditions of the Creative Commons \\ Attribution-ShareAlike 4.0 International License-(CC-BY-SA) (https://creativecommons.org/licenses/by-sa/4.0/) \\ DOI : http://dx.doi.org/10.30983/islam_reality.v7i2.4817 \\ \begin{tabular}{l|l|l} 
Submission: 23 September 2021 & Revised: 27 December 2021 & Published: 31 December 2021
\end{tabular}
}

\begin{abstract}
The purpose of this study is to analyze the Covid-19 Muhammadiyah Islamic boarding school's complete independent isolation model. The subjects of this study consist of Covid-19 patients and leaders of the Covid-19 Islamic boarding schools. This research uses a qualitative approach with a case study type. This research was conducted at the Covid-19 Muhammadiyah Islamic Boarding School in Yogyakarta, which was located at the PKU Muhammadiyah Hospital in Yogyakarta. Data collection techniques uses direct interviews, observation and documentation. The data analysis technique followed the Miles and Huberman model, namely data display, data reduction, and data verification. The validity of the data uses triangulation. The results show that the approach model used was complete self-isolation on psychosocial and neurospiritual aspects. With the development of social relations on the psychosocial aspects, patients feel healthy and not stressed. The increase in spiritual neurospiritual perspectives has helped the immunity of Covid-19 patients to remain stable and further encouraged the performance of good deeds. This research has implications for Covid-19 patients in repairing and coaching related to social behavior and religious behavior during the pandemic.
\end{abstract}

Keywords: Muhammadiyah Covid-19 Islamic Boarding School, Covid-19 patients, immune, faith.

\begin{abstract}
Abstrak
Tujuan penelitian ini menganalisis pesantren Covid-19 Mubamamdiyah dengan model Isolasi mandiri paripurna. Subjek, penelitian ini terdiri dari pasien Covid-19 dan pimpinan pesantren Covid-19. Penelitian ini menggunakan pendekatan kualitataif jenis studi tudi kasus. Penelitian ini dilakukan di pesanren Covid-19 Mubamamdiyah Yogyakarta yang bertempat di Rumah sakit PKU Mubammadiyah Yogyakarta. Teknik pengumpulan data menggunakan metode wawancara langusng, observasi dan dokumentasi. Teknik analisis data mengikuti model Miles dan Huberman yaitu display data, reduksi data, dan verifikasi data. Keabsahan data menggunakan triangulasi. Hasil penelitian menunjukkan bahwa model pendekatan yang diguanakn isolasi mandiri paripurna, pada aspek. psikososial dan Neurospiritual. Dengan adanya pembinaan bubungan sosial pada aspek psikososial pasien merasa sehat dan tidak stress. Adapun peningkatan imam dan spiritual perpespektif neurospiritual membantu imun pasien Covid-19 tetap stabil dan lebih baik amal sholehnya. Penelitian ini berimplikasi terbadap pasien Covid-19 dalam perbaikan dan pembinaan yang berbubungan dengan prilaku sosial dan prilaku beragama di masa Covid-19.
\end{abstract}

Kata Kunci: Pesantren Covid-19 Mubammadiyah, Pasien Covid-19, Imun, Iman

\section{Background}

Indonesia is one of the most affected countries by Covid-19. As of February 1, the rate of the spread of Covid-19 showed an increasingly higher increase. ${ }^{1}$ Data from the Covid-19 task force showed that the number of confirmed cases of Covid-19 had reached 1.11 million and resulted in 30,770 deaths (fatality rate of $4.150,000$ results

1 Marisol J. Voncken and others, 'The Effect of Intranasally Administered Oxytocin on Observed Social Behavior in Social Anxiety Disorder', European

Neuropsychopharmacology, $53.3 \quad$ (2021), 25-33 <https://doi.org/10.1016/j.euroneuro. 2021.07.005>. 
(0.62 seconds). ${ }^{2}$ The Covid-19 response policy as stated in Law no. 2 in 2020 and costing a budget of 400.0 trillion did not have the slightest impact on controlling the spread of Covid-19. This is exacerbated by the religious response that tends to be negative. ${ }^{3}$ Many groups in the Islamic community still consider Covid-19 a global conspiracy and carry out anti-science and antiintellectualist propaganda to influence the religious scholars' (ulama) legal rulings (fatwa) on preventing Covid-19. ${ }^{4}$ This condition resulted in the peak of the spread of Covid-19 in Indonesia as a whole until it became a red zone. ${ }^{5}$

The high number of Covid-19 patients, on the one hand, and limited health facilities, on the other, have resulted in the neglect of Covid-19 patients, especially those without symptoms (OTG). Covid-19 patients with severe symptoms are mostly accommodated in hospitals, while patients with mild symptoms are only required to self-isolate, without health facilities from the state. ${ }^{6}$ As for those without symptoms, they have to self-isolate in their respective residences.

2 Radoslaw Kotkowski and Michal Polasik, 'COVID-19 Pandemic Increases the Divide between Cash and Cashless Payment Users in Europe', Economics Letters, $209.2 \quad$ (2021), 110139 <https://doi.org/10.1016/j.econlet.2021.110139> .

3 Csilla Lea Fazekas and others, 'Pharmacogenetic Excitation of the Median Raphe Region Affects Social and Depressive-like Behavior and Core Body Temperature in Male Mice', Life Sciences, 286.2 (2021), 1-10 <https://doi.org/ 10.1016/j.lfs.2021.120037>.

${ }_{4}$ Veronica Renov and others, 'The Impact of the COVID-19 Pandemic on Child Protective Services Caseworkers and Administrators', Child Abuse \& Neglect, 3.August (2021), 105431

<https://doi.org/10.1016/j.chiabu .2021.105431>.

5 Amanda J. Barabas and others, 'Modulating Captive Mammalian Social Behavior: A Scoping Review on Olfactory Treatments', Applied Animal Behavior Science, 244.July (2021), 105489 <https://doi.org/10.1016/j.applanim. 2021.105489>.

6 Carla Ickert, Rachel Stefaniuk, and James Leask, 'Experiences of Long-Term Care and Supportive Living Residents and Families during the COVID-19 Pandemic: "It's a Lot Different for Us than It Is for the Average Joe"', Geriatric Nursing, $42.6 \quad$ (2021), 1547-55 <https://doi.org/10.1016/j.gerinurse.2021.10.012>.

Meghan B. Smith and others, 'Making It (Net)Work: A Social Network Analysis of "Fertility" in Twitter before and during the COVID-19 Pandemic', F\&S
However, self-isolating OTG patients experience have been ostracized and discriminated against by the surrounding community, ${ }^{8}$ due to the lack of guidance and direction from the medical professionals and closest family members. This weakens the spirit and body's immune power, especially the strength of their faith, given lack of spiritual touch from religious leaders.' Thus, self-isolation for asymptomatic Covid-19 patients is not a solution at all. ${ }^{10}$ Asymptomatic patients who should have recovered after 14 days of self-isolation have not yet recovered, some have even recovered for up to 30 days. ${ }^{11}$ They are not sick because of Covid19 but more because of social isolation and suffering by the surrounding community. Therefore, an alternative isolation model is needed that does not isolate and marginalize Covid-19 patients. $^{12}$ They should be able to continue to live in isolation but still socialize with other people.

In this case, the Muhammadiyah COVID19 Islamic boarding school is a promising

Reports, $2.4 \quad$ (2021), 472-78 <https:/
/doi.org/10.1016/j.xfre.2021.08.005>.
8 Rita Latikka and others, Loneliness and Psychological Distress before and during the COVID-19 Pandemic: Relationships with Social Media Identity Bubbles, Social Science \& Medicine (Elsevier Ltd, 2021)

<https://doi.org/10.1016/j.socscimed.2021.114674>.

${ }^{9}$ Julia Strojny and others, 'The Modulation of Social Behavior and Empathy via Oral Contraceptives and Female Sex Hormones', Psychoneuroendocrinology, 131.December $2020 \quad$ (2021), 105250 <https://doi.org/10.1016/j.psyneuen.2021.105250> .

10 Yukiyoshi Hyo and others, 'Survey of Nebulizer Therapy for Nasal Inflammatory Diseases in Japan before and during the COVID-19 Pandemic', Auris Nasus Larynx, 8.xxxx (2021), 1-10 <https://doi.org/10.1016 /j.anl.2021.11.007>.

11 Chinazo O. Cunningham and others, 'A Comparison of Office-Based Buprenorphine Treatment Outcomes in Bronx Community Clinics before versus during the COVID-19 Pandemic', Journal of Substance Abuse Treatment, August, 2021, $108641<$ https://doi.org /10.1016/j.jsat.2021.108641>.

12 Zhong Zhang and others, 'Impacts of COVID-19 Pandemic on the Aquatic Environment Associated with Disinfection Byproducts and Pharmaceuticals', Science of the Total Environment, 2.xxxx (2021), 151409 <https://doi.org/10.1016/j .scitotenv.2021.151409>. 
alternative for asymptomatic patients. ${ }^{13}$ They are gathered in one community and undergo medical treatment. In this place, they are able to foster social relationships and undergo spiritual cleansing. ${ }^{14}$ With this approach, there is a chance to become better and healthier. ${ }^{15}$ The provision of medical care supported by social relations with other people is has shown to have a positive outcome. ${ }^{16}$ Furthermore, the model is developed with the spiritual touch of religious leaders. ${ }^{17}$ This leads to a plenary-based self-isolation model organized by a hospital with an accredited status. ${ }^{18}$ This means that the Muhammadiyah Covid-19 Islamic boarding school has shown to be very effective in providing Covid-19 patients with happiness and health. ${ }^{19}$

So far, studies on self-isolation for asymptomatic Covid-19 patients are still in the form of ordinary alternatives such as selfisolation. ${ }^{20}$ This can be seen, for instance, in the research of Silvia et al., 2020, "Development of the PERISAI Information System (SelfReporting during Isolation) for People Under Covid-19 Monitoring" which focuses on the selfisolation model. ${ }^{21}$ The same issue was also investigated by Novia Wirna Putri 2020, "Health Education for Independent Isolation in the effort to handle Covid-19 in Kangarian Koto Baru, Solok Regency." The focus of these studies is on self-isolation and efforts to handle Covid-19. ${ }^{22}$ Thus there has been no research on a selfisolation model in the form of a COVID-19 boarding school, which not only facilitates health but also fosters social relationships and increases faith. ${ }^{23}$ This model optimizes the healing of COVID-19 OTG patients by increasing faith and immunity with a complete self-isolation model. This paper examines this important alternative to Covid-19 patients—which has received accreditation A hospital rating-from a neurospiritual and psychosocial perspective.

The purpose of this study is to study a complete self-isolation model with a psychosocial and neurospiritual approach represented by the Covid-19 Islamic boarding school. The purpose of this research can be described in three aspects: first, healthcare for Covid-19 patients. Second, fostering social relations and thirdly developing faith and spiritual development programs for Covid-19 OTG patients. This model provides
13 Adam Schwertner, John McMenamy, and David M. Naeger, 'Radiology Imaging Volume Changes During Discrete COVID-19 Pandemic Waves: Implications for the Delta Variant of Coronavirus and Future Pandemics', Journal of the American College of Radiology, 3.December (2021 )

<https://doi.org/10.1016/j.jacr.2021.09.045>.

14 Brick Johnstone, Daniel Cohen, and Andrew Dennison, 'The Integration of Sensations and Mental Experiences into a Unified Experience: A Neuropsychological Model for the "Sense of Self", Neuropsychologia, 159.June (2021) <https://doi. org/10.1016/j.neuropsychologia.2021.107939>.

15 Voncken and others.

16 Syifa Nadiah, Nadia Aulia Nadhirah, and Irfan Fahriza, 'Relationship of Psychosocial Development Factors and Vocational Identity in Late Adolescence', Quanta, $5.1 \quad$ (2021), 21-29 <https://doi.org/10.22460/q.v1i1p1-10.497 >.

${ }^{17}$ Nadiah, Nadhirah, and Fahriza.

18 Tajul Arifin and others, 'Self Protection During the COVID-19 Pandemic Based on Sahih Hadith', Living Islam: Journal of Islamic Discourses, 1.2 (2020), 1-15 <http://digilib.uinsgd.ac.id/30833/> .

19 Suyadi, Zalik Nuryana, and Niki Alma Febriana Fauzi, 'The Figh of Disaster: The Mitigation of Covid-19 in the Perspective of Islamic Education-Neuroscience', International Journal of Disaster Risk Reduction, 51.2 (2020), 101848 <https:/ /doi.org/10.1016/j.ijdrr.2020.101848>.

20 Keely A. Muscatell and Tristen K. Inagaki, 'Beyond Social Withdrawal: New Perspectives on the Effects of Inflammation on Social Behavior', Brain, Behavior, \& Immunity - Health, 16.July (2021), 100302 <https://doi .org/10.1016/j.bbih.2021.100302>.

21 Emily G. Vira and Therese Skoog, 'Swedish Middle School Students' Psychosocial Well-Being during the COVID-19 Pandemic: A Longitudinal Study', SSM Population Health, 16.August (2021), $100942<$ https://doi. org/10.1016/j.ssmph.2021.100942>.

22 Eszter Nagy and others, "The Impact of the COVID-19 Pandemic on Autoimmune Diagnostics in Europe: A Lesson to Be Learned', Autoimmunity Reviews, 20.August (2021) <https://doi.org/10.1016/j.autrev .2021.102985>.

${ }^{23}$ Rafael Guimarães dos Santos and Jaime Eduardo Cecilio Hallak, 'Ayahuasca, an Ancient Substance with Traditional and Contemporary Use in Neuropsychiatry and Neuroscience', Epilepsy \& Behavior, 121 (2021), 106300 <https://doi.org/https://

doi.org/10.1016/j.yebeh.2019.04.053>. 
mental and physical healing to patients who previously lacked attention and motivation from those closest to them. These patients experienced depression, stress, fear, and panic due to their condition.

This research is based on the argument that complete self-isolation for Covid-19 (OTG) patients with a psychosocial and neurospiritual approach (such as Islamic boarding school Covid19 Muhammadiyah) is the best solution for reducing the risk of spreading Covid-19 in Indonesia. ${ }^{24}$ For example: contributions to hospitals that provide Covid-19 patients with increasing tips recorded in the statistical data on the spread of Covid- $19 .{ }^{25}$ This kind of service can assist the prevention of Covid-19 clusters. Among other things, hospitals or health centers providing Covid-19 care are receiving more and more patients every week. There also Covid-19 ODP patients, which are increasing every day. This makes the health system overwhelmed in addressing the problem. Thus, complete selfisolation is one of the alternatives for handling the spread of Covid-19, which involves physical healing by the health medical team, building social relationships, and religious guidance (spirituality).

The research approach used in this study is qualitative. ${ }^{26}$ The reason for using this method is because we want to understand and interpret the social behavior of Covid-19 patients, both OTG and Covid-19 patients who are infected with the virus, who participate in Covid-19 Islamic boarding schools. We use a psychosocial and neurospiritual approach. The case study is the Covid-19 Muhammadiyah Islamic boarding school located at PKU Muhammadiyah Yogyakarta. In this study, the research subjects are Covid-19 OTG patients, other Covid-19 patients, the Director of the Muhammadiyah Islamic boarding school, and Muhammadiyah Yogyakarta MCCC. From the four research subjects, we would obtain complete data regarding social behavior, psychological and spiritual impacts, using a neurospiritual approach. The determination of research subjects was done by purposive sampling technique. According to Sugiyono, ${ }^{27}$ this particular consideration is an example of the person who is considered to know best about what we expect, or perhaps he is a leader so that it will make it easier for researchers to trace the object or social situation under study.

The data collection technique was carried out using the interview, observation, and documentation methods. First, in-depth interviews are guided by the interview guide and are not structured. Interviews are the primary data in this study. The interview was intended to obtain data by asking questions regarding social behavior, psychosocial aspects, and neurospiritual approaches related to the social behavior of Covid-19 patients at the Muhammadiyah Covid-19 Islamic boarding school. Informants who will be interviewed are the director of the Covid-19 Islamic boarding school, Covid-19 patients OTG or not exposed to Covid-19, MCCC Covid-19 Muhammadiyah Yogyakarta. Second, observations are made by obtaining information about social behavior, psychological aspects, and the spiritual response of Covid-19 patients using a neurospiritual approach on activities held at the Muhammadiyah Covid-19 boarding school. Observations carried out are formal and informal.

Third, documentation. The documentation that will be studied is the texts and photos of the activities of Covid-19 patients while in selfquarantine at the Covid-19 Islamic boarding school, both in their social, spiritual, and psychosocial aspects. We examine photos, archives of cult training documents, and religious advice geared towards improving the spiritual and faith of Covid-19 patients during the Covid-19 pandemic, as well as other notes related to the
${ }^{24}$ Nicolas Palanca-Castan, Beatriz Sánchez Tajadura, and Rodrigo Cofré, 'Towards an Interdisciplinary Framework about Intelligence', Heliyon, 7.2 (2021), e06268 $<$ https://doi.org/10.1016/j.heliyon.2021.e06268>.
${ }^{25}$ Johnstone, Cohen, and Dennison.

26 Sugiyono, Qualitative Quantitative Research Methods and R\&D, 1st edn (Bandung: Alfabeta, 2017).

27 Sugiyono. 
activities of Covid-19 patients at the Muhammadiyah Covid-19 Islamic boarding school. In this study, this type of data analysis uses the Miles and Huberman method (Miles \& Huberman, 2000), namely the activities in qualitative data analysis are carried out interactively and take place continuously until complete so that the data is saturated. Activities in data analysis are reduction, data display, and conclusion drawing/verification. Three main activities are interrelated and occur simultaneously, namely data reduction, data display, and conclusion drawing or data verification. $^{28}$

\section{Muhammadiyah Covid-19 Islamic Boarding School}

The Muhammadiyah Covid-19 Islamic Boarding School is a health community institution that handles Covid-19 OTG patients with a complete self-isolation model that focuses on three alternative aspects, namely, first, improvement and healing by the medical team against Covid-19 patients, secondly, fostering

The researchers interviewed the director of PKU Muhammadiyah Yogyakarta Hospital. The discussion lead to the origins of the Muhammadiyah Covid-19 Islamic boarding school, which is located at the PKU Muhammadiyah Hospital in Yogyakarta, and is located at Aisiyah University, Yogyakarta. These two places are alternatives responses to the Covid-19 Islamic boarding school.

The researcher continued his interview with the director of PKU Muhammadiyah Yogyakarta Hospital, who said:

"The strategy and function of the Covid-19 Islamic boarding school is to be an alternative to Covid-19 patients who are rejected by hospitals in general. One of the approaches that Covid-19 Islamic boarding schools have social relations among communities and others who are trained to maintain communication and have familiarity with the boundaries and rules of health protocols, and thirdly the development of faith and immunity development for Covid-19 OTG patients.

The PKU Yogyakarta Hospital Director explains the establishment of the Covid-19 Islamic boarding school in the following terms:

"For the first time, the existence of a Covid19 Islamic boarding school began with an increase in Covid-19 patients who contracted Covid-19. The Covid-19 OTG patients who were affected without symptoms also followed. At that time, all the hospitals in the city of Yogyakarta were very full, sir. There are even hospitals during the closed Covid-19 that do not want to accept sick patients, even though they are sick without Covid-19 symptoms. Therefore, we together with a small team from PKU Yogyakarta Hospital had a small meeting in the discussion room of the PKU Muhammadiyah Yogyakarta hospital" 29

is known as complete self-isolation. It is engaged in the field of psychosocial and neurospiritual treatment. We know that the Covid-19 patient, for the OTG, is not sick because he was exposed to the Covid-19 virus. However, since they are being ostracized, the psychosocial impact is unstable, and their spirituality is declining. Therefore, one of its functions and goals is a neurospiritual approach, which focuses on the patient's brain which is directed to increase faith and pray." 30

From the results of the interview above, the strategy carried out by the Muhammadiyah Covid-19 Islamic boarding school is that Covid19 patients are given a plenary self-isolation approach which aims to regulate Covid-19 patients social behavior and keep social

${ }^{28}$ Sugiyono.
29 Taufiqurrahman, (Leader of the Muhammadiyah Covid-19 Islamic Boarding School) Interview, \{ Monday, 21 February 2021\}

30 Taufiurrahman, (Leader of the Muhammadiyah Covid-19 Islamic Boarding School) Interview, \{Monday, 21 February 2021 
relationships active. Supported by a psychosocial approach, they are given advice, engage in sports with a religious approach, religious lectures, all for the sake of increasing faith and prayers.

The researcher continued the results of his interview with the director of the Muhammadiyah Covid-19 Islamic boarding school, who said:

"The development of the Muhammadiyah Covid-19 Islamic boarding school is different from the handling of other Covid-19 preventions. The Muhammadiyah Covid-19 Islamic Boarding School is known for its plenary self-isolation approach. We are recommended and supported by hospitals with plenary status (best hospital service accreditation). Our approach is in contrast to the self-isolation model in general, which emphasizes physical health healing only. We engage on public relations and increasing faith and immunity (psychosocial). This is often experienced by Covid-19 OTG patients without the attention and support of the closest people and the surrounding community. The community ostracizes and discriminates against them because they have been confirmed positive for Covid-19. There is also rejection by hospitals that are less willing and reluctant to accept." 31

From the results of the interview conversation above the Muhammadiyah Covid19 Islamic Boarding School is catered specifically for OTG Covid-19 patients (people without symptoms) who are refused by hospitals and the community due to the fear of being infected and contracting Covid-19. Now the Covid-19 Islamic boarding school is a place to accommodate the Covid-19 patients. The activities in it are the same as other non-permanent boarding school, which usually starts from four in the morning to nine at night. This is very different from the usual quarantine model which is quite sad with exclusion and discrimination.

\section{Healthcare for Covid-19 patients at Muhammadiyah Islamic Boarding School}

The treatment provided by the health medical team from the Muhammadiyah Covid-19 Islamic boarding school is carried out continuously daily. The school strictly carries out the health protocol as informed by one of the students (Covid-19 OTG patient), who said that he feels "happy and grateful even though at the Muhammadiyah Covid-19 Islamic boarding school. Treatment is no less important and is controlled by the health medical team everyday." The services provided by the health medical team include carrying out health checks every day. This means that the developments that emerge from the santri (Covid-19 OTG patients) are monitored continuously. One of the pieces of evidence is the report on the WhatsApp Health Group facility for the Muhammadiyah OTG Covid-19 patient. The health services of the Muhammadiyah Covid-19 Islamic boarding school are more pressing and is optimized for the recovery of a strong immune system. This is completed with a quarantine isolation model and a psychosocial and spiritual approach to Covid-19 patients. This is in contrast to the exclusion and discrimination by the local community and rejection by the surrounding hospital.

Based on interviews with Covid-19 patients, the following are the services and treatments at the Muhammadiyah Covid-19 Islamic boarding school:

"During the self-service process at the Covid19 Islamic Boarding School, the services at the Covid-19 Islamic Boarding School are like hospital services in general. During our healing process, the medical team still emphasized maintaining the health protocol with the $3 \mathrm{M}$, namely washing hands, wearing masks, avoiding crowds. Our food and drink are perfectly supported by a healthy 45 perfect breakfast. But we are stressed that every day there is exercise together and exercise in the morning and afternoon. To

31 Taufiurrahman, (Leader of the Muhammadiyah Covid-19 Islamic Boarding School) Interview, \{Monday, 21 February 2021 
differentiate from hospitals which in general are Covid-19 Islamic boarding schools, they are still given motivation and spiritual strengthening. The bonus is that the service from the medical team is very good." 32

The above is from an interview with a Covid19 patient at the Muhammadiyah Covid-19 Islamic boarding school. This means that the detailed treatment carried out is to always maintain the health protocol of wearing masks, maintaining distance, and washing hands. Masks that have been used are ordered to be discarded and are not suitable for use. Nutritious intake is given, exercise and sunbathing in the morning are offered every day. There are also checks of the bedrooms and bathrooms of the Muhammadiyah Covid-19 Islamic boarding schoolroom.

The researcher continued the results of his interviews with Covid-19 patients, and received the following responses from the Covid-19 Islamic boarding school:

"How about your comments and input while at the Covid-19 Islamic boarding school? It was good, sire, I just feel entertained and get a lot of new learning and experiences there. Even though we are together as Covid-19 comrades in arms, there are even 50 members of the Covid-19 patient, our solidarity is maintained. We eat together, exercise together, and study together. We can also meet with the family at home. The family comes here. So, we don't feel alone anymore, we already have a family to visit and accompany us. But this is still limited by a strong health protocol." ${ }^{13}$

In line with the results of the informant with the Covid-19 patient, the behavior of the Covid19 patient was maintained. Physical health immunization is supported by exercise and regular eating. Physical health is supported by religious counsel and healthy-spirit motivation.

\footnotetext{
32 Heru, (Pasien Covid-19) Interview, \{Monday, 21 February 2021\}.

33 Wawali (Pasien Covid-19 OTG\} Interview, \{Monday, 21 February 2021\}

34 Wawali, (Pasien Covid-19) Interview, \{Monday, 21 February 2021\}.
}

This means that the Covid-19 patient' happiness hormone can increase dramatically. Spiritual enhancement adopts a neurospiritual approach that are supported by researchers. In neuroscience, if the brain is supported by a spiritual approach, the brain will greatly affect other body parts.

A Covid-19 patient related the following experience at the Muhammadiyah Covid-19 Islamic boarding school:

"The Covid-19 Islamic boarding school is very open to the public, sir. I feel grateful sir, just imagine that at that time there were many rejections of other sick people who were refused. Our friends who have been in self-isolation in other places have been ostracized; even the medical team is not as attentive as the health services at this Muhammadiyah Covid-19 Islamic boarding school. Here we are trained and required to pray five times a day, read the Qur'an, and recite religious counsel from the ustadz (teacher). We carry out the sunnah (supererogatory) prayer, tahajjud (night) prayer, dhuha (afternoon) prayer, tadarus (study of) al-Qur'an after each prayer. We also study through Zoom meetings. We even have sports facilities and Wifi facilities." 34

This means that the Covid-19 patients feel comfortable and happy during the process of selfisolation at the Covid-19 Islamic boarding school. Moreover, the Covid-19 Islamic boarding school prioritizes and emphasizes psychosocial and neurospiritual approaches with worship activities that strengthen faith and immunity. For Covid-19 patients, the emphasis is on increasing faith through religious lecture, Zoom meetings, and prayer to approach closer to Allah.

The neurospiritual cortex is found in the in the Qur'an with nasyiyah. This helps Covid-19 patients by giving them extraordinary enthusiasm. Neurospirituality is closely related to the pattern of human life in the world. ${ }^{35}$ This includes the

35 Sophia Weiner-Light and others, 'The Role of Spirituality in Conceptualizations of Health Maintenance and Healthy Aging Among Latin American Immigrants', The American Journal of Geriatric Psychiatry, 29.11 (2021), 1079-88 https://doi.org/10.1016/j.jagp.2021.04.017>. 
model offered at the Muhammadiyah Covid-19 Islamic boarding school, which is based on the complete self-isolation. This is achieved byy prioritizing increasing immunity and faith in activities carried out by Covid-19 patients.

\section{Fostering Social Relations among Covid-19 Patients}

Fostering social relations was carried out in the Muhammadiyah Covid-19 Islamic boarding school to maintain communication and familiarity with other Covid-19 fellows. Greeting each other and sharing opinions to motivate each is important to strengthen the immune system. Thus, Covid-19 patients have a family relationship with each other and the environment is very supportive for their speedy recovery from Covid-19. It could be said that those who previously felt isolated and were ostracized became happy, and found a new power after spending time with other people like them.

MCCC Muhamamdiyah Yogyakarta city is part of the management at the Covid-19 Islamic boarding school. In one interview, the following was stated:

"Social relations are also carried out to relieve boredom from quarantine and isolation for days, to overcome the most important psychological impact of Covid-19 patients, namely depression, stress, and excessive anxiety. The feeling of being unable to cope independently with the development of social relationships is getting better. The existence of training on how to have good and healthy relationships and how to communicate healthily is directed at fostering social relations. Maintaining relationships and communication is part of recovering from depression and stress so that unsupportive feelings and thoughts go away, and they don't feel alone-that there are people closest to them who always support them." ${ }^{\prime 36}$

The above is the result of an interview with MCCC Muhammadiyah City of Yogyakarta at the Covid-19 Islamic Boarding School, which is part of the structure and management of the Muhammadiyah Covid-19 Islamic Boarding School. Coaching is very important to improve social behavior during the Covid-19 period. Exchanging opinions, sharing experiences, and motivating each other among Covid-19 patients are also conducted. This social relationship development is part of a program that is emphasized in Covid-19 Islamic boarding schools during the Covid-19 pandemic. To increase immunity and have a good psychological impact must come together, because, on the one hand, Covid-19 patients are very far from their families. Of course, it requires sharing experiences and strong motivation.

\section{Faith and Spirituality Building Program}

One important aspect of the improvement and health of Covid-19 patients is the development of faith and spirituality through improvement programs. OTG Covid-19 patients were given direction and guidance to increase faith and immunity by the Muhammadiyah Covid-19 Islamic boarding school. One example is the existence of a religious worship program beginning with mandatory prayers, which are held regularly and consistently five times a day in Islamic boarding schools. This is also coupled with sunnah prayers such as tahajud and dhuba carried out as routine activities. The Qur'an tadarus program is carried out after prayers. This activity is emphasized and optimized by the Muhammadiyah Covid-19 Islamic boarding school so that faith and immunity remain stable.

One very supporting program is the existence of online recitation activities held by the manager of the pesantren. The online media Zoom model run by the ustadz with a theme that is very supportive and follows the COVID-19 OTG patient. This began with the theme "related to faith, increasing faith, because faith is the foundation and direction of human

36 Sigit (Leader MCCC Muhammadiyah Yogyakarta) Interview, \{Monday, 21 February 2021\}. 
belief.” As explained by one ustadz who presented on the theme about faith, "if the faith of a Muslim community increases universally, attitudes and beliefs become better and more focused." This is coupled with improvements related to immunity such as improved lifestyle and psychological effects (depression and stress).

This is an approach that focuses on psychosocial and neurospirituality with a complete independent isolation model for COVID-19 OTG patients. The live strong support and motivation to positive patients that Covid-19 is a test, and they believe that every test has a better reward. One should not complain to other people; it is better to pray to Allah and get support from family and closest friends. Guidance and direction on good behavior with a healthy and clean lifestyle, and remaining optimistic all lead to psychosocial and spiritual improvement in the Muhammadiyah Covid-19 Islamic boarding school. The following is a tabulation based on informants from the results of interviews, analyzed by researchers in tabular form:

Table 1: Islamic Boarding School Covid-19 Muhammadiyah

\begin{tabular}{lll}
\hline No & Ustadz name & Material Theme \\
\hline $\mathbf{1 .}$ & Dr. Suyadi, M.Pd.I & $\begin{array}{l}\text { Muhammadiyah } \\
\text { Covid-19 Islamic } \\
\text { Boarding School }\end{array}$ \\
\hline 2. & $\begin{array}{l}\text { dr. Adnan Abdullah, } \\
\text { Sp. ENT-KL PKU }\end{array}$ & $\begin{array}{l}\text { Olfactory Disorders } \\
\text { in Covid-19 Patients } \\
\text { and the Benefits of } \\
\text { Nasal Wash }\end{array}$ \\
& Hospital Yogyakarta & $\begin{array}{l}\text { The Concept of Pain } \\
\text { in the Context of an } \\
\text { Outbreak }\end{array}$ \\
\hline 3. & Dewi Yuniasih, M.Sc & Law \\
& Royan Utsany, Lc, & $\begin{array}{l}\text { Islamic } \\
\text { Perspective Vaccine }\end{array}$ \\
\hline $\mathbf{5 .}$ & DHI Elli Nurhayati, & Reframing \\
& M.PH., Ph.D., & \\
\hline
\end{tabular}

Based on the results of the tabulation above, to increase the faith and spiritual power of Covid-
19 patients is supported by religious counsel in the form of Zoom meetings, which has been arranged and scheduled by the management or committee of the Muhammadiyah Covid-19 Islamic boarding school with the meeting id and password. The speakers were given different themes. Eighty percent of Covid-19 patients responded very well to the contents of the lecture material delivered by the presenters, starting with the theme of the Covid-19 Islamic boarding school Muhamamdiyah from a neuroscience perspective delivered by Suyadi 2020, until the final one delivered by Margianto, with the theme "Taqwa and Hifzun Nafs" with the meeting id and password. ${ }^{37}$

However, in research, this is combined with the brain approach and a spiritual approach, which is called neurospiritual. The neurospiritual perspective of science explains how human spiritual values is closely related to the brain. Suyadi 2020 has explained in his book, entitled Tracing the Brain Traces in the Perspective of the Qur'an and Neuroscience, that the brain is not only used in medical science, but it is also medical. ${ }^{38} \mathrm{But}$ the brain can also be linked with other scientific perspectives in transdisciplinary, interdisciplinary, multidisciplinary discussions. This includes the brain juxtaposed with spiritual approaches or spiritual values.

\section{Spiritual Improvement of OTG Covid-19 Patients from a Neurospiritual Perspective}

Neurospiritual is a term used by Taufiq Pasiak to denote a subdiscipline of neuroscience that specializes in the study of the brain and human spirituality. The focus of spirituality in neuroscience is for example on meditation, prayer, forgiveness, love, hope, rituals, and myths which are all seen from the perspective of the brain and the implications it causes. Therefore, spiritual neuroscience is more focused on
37 Mohammad Jailani, Suyadi, and Dedi Djubaedi, 'Traveling the Traces of the Brain and 'Aql in the Qur'an from the Perspective of Neuroscience and Islamic Education in the Era of the COVID-19 Pandemic', Tadris: Journal of Islamic Education, 16.1 (2021), 1-19 < https://doi.org/10.19105/tjpi.v16i1.4347>.
38 Suyadi and Hendro Widodo, 'Millennialization Of Islamic Education Based On Neuroscience In The Third Generation University In Yogyakarta Indonesia', QIJIS: Qudus International Journal of Islamic Studies, 7.1 (2019), 173-202 < <ttps://doi.org/DOI 10.21043/qiiis.v7i1.4922>. 
practicality in the fields of health and medicine. With this practical focus, neurospiritual is more focused on internalizing certain values and then externalizing those values in human life. ${ }^{39}$

This is included by the researchers as a perspective from the social behavior and individual behavior of Covid-19 patients who were previously ostracized and avoided by the community due to their illness. The findings of neuroscience provide empirical support for the existence of a biological framework in the human brain when a person is in a mystical or spiritual state, regardless of religion. Several genes code for chemical mechanisms and areas of spirituality in the brain have been identified. ${ }^{40}$ One of them is a gene encoding a protein that carries the neurotransmitter serotonin, which is one of the monoamine group neurotransmitters that affect spirituality by changing consciousness, which can be broadly defined as our sense or sensitivity to reality, awareness about ourselves and the universe around us, including our thoughts, memory, and perception. The following is a neurospiritual interpretation:

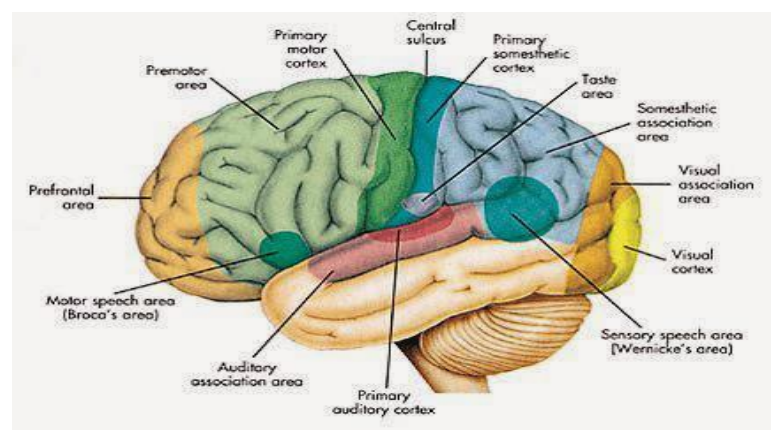

Figure 1. Neurospiritual

39 Rebecca Alexander and others, 'The Neuroscience of Positive Emotions and Affect: Implications for Cultivating Happiness and Wellbeing', Neuroscience and Biobehavioral Reviews, 121 (2021), 220-49 $<$ https://doi.org/10.1016/j.neubiorev. 2020.12.02>.

40 Afzal Javed and others, 'Reducing the Stigma of Mental Health Disorders with a Focus on Low- and MiddleIncome Countries', Asian Journal of Psychiatry, 58.December $2020 \quad$ (2021), 102601 <https://doi.org/10.1016 /j.ajp.2021.102601>.

41 Pietro Matracchi and Ali Sadeghi habibabad, 'Prioritizing the Effect of "Light" in the Religious Places and Environments with an Emphasis on the Sense of
As for spirituality, Taufik Pasiak pays full attention to the prefrontal cortex without neglecting other parts of the brain. Self-awareness cannot be separated from the cognitive aspect of the brain, because every conscious action is related to sensation, memory, and perception. This is one of the important roles of the frontal cortex. ${ }^{41}$ According to Pasiak, the prefrontal context area in the human brain is the most developed part of the brain and occupies 30\% of the human brain. In the prefrontal cortex too, the meaning of life and the human ability to distinguish good and bad can be observed. The meaning of life itself is part of spirituality. ${ }^{42}$ In the anatomy of the human brain, the position of the prefrontal cortex is in the front area of the frontal lobe. The creation of spirituality in the prefrontal cortex is in the front area of the frontal lobe. ${ }^{43}$ The creation of spirituality in the prefrontal cortex cooperates with other brain parts such as the prefrontal cortex, cingulate gyrus, basal ganglia, temporal lobe, limbic system, and anatomical nervous system. This component is then referred to by Pasiak as a neurospiritual operator.

\section{Development of Social Relations Psychosocial perspective}

One of the efforts of the Covid-19 Islamic boarding school is fostering good social relations. Covid-19 patients need to be nurtured and encouraged to keep their immune and stress levels stable. As a result of the relentless Covid-19 virus, it has more or less affected Covid-19 patients. $^{44}$ Therefore, the Covid-19 Islamic boarding school made efforts with the PKU Muhamamdiyah

Spirituality', Ain Shams Engineering Journal, 13.1 (2021), 101514 <https://doi.org /10.1016/j.asej.2021.05.028>.

42 Javed and others.

43 Dilip V Jeste and others, 'Is Spirituality a Component of Wisdom? Study of 1,786 Adults Using Expanded San Diego Wisdom Scale (Jeste-Thomas Wisdom Index)', Journal of Psychiatric Research, 132.9 (2021), 174-81 <https://doi.org/https://doi.org/10.1016 /j.jpsychires.2020.09.033>.

44 Jane B. Hopkinson, 'The Psychosocial Components of Multimodal Interventions Offered to People with Cancer Cachexia: A Scoping Review', AsiaPacific Journal of Oncology Nursing, 8.5 (2021), 450-61 <https://doi.org/10.4103 /apjon.apjon-219>. 
Yogyakarta medical team to provide guidance and training to add positive energy to Covid-19 patients. This takes the form of education, such as doing online courses by responding to Covid19 patients with interesting themes.

Therefore, psychosocial assistance or support from other parties, including the Covid19 Islamic boarding school, is needed to respond well. When the community and hospitals avoid it, one alternative is for COVID-19 OTG and ODP patients to be embraced and given alternatives or solutions. ${ }^{45}$ An alternative is a complete selfisolation approach that leads to psychosocial aspects that aim to protect or improve psychological well-being and prevent and treat mental and psychosocial health conditions. ${ }^{46}$

In developmental psychology, much has been discussed about the stages of social development in children, adolescents, and society. Among the figures who contributed in this field, is Erik H. Erikson with his theory of psychosocial development. Erikson said that the term "psychosocial" concerning human development means that the stages of a person's life from birth to death are shaped by social influences that interact with an organism that makes a person physically and psychologically mature. ${ }^{47}$

Psychosocial, of course, is not only for COVID-19 OTG and ODP patients, but individuals who have recovered from Covid-19. Support for these people include meeting basic needs, reducing emotional stress, sharing positive information, increasing and maintaining positive relationships, reducing stigma, and increasing resilience health workers, and close family and relatives, who also need psychosocial support. These are some of the things that can be done as a form of psychosocial support.

\section{Conclusion}

Based on the results and discussion, it can be concluded that with the existence of the Covid-19 Islamic boarding school, Muhammadiyah helps Covid-19 patients stay healthy and maintain their immunity and stress. OTG Covid-19 patients and ODP patients who were previously rejected in all hospitals were even ostracized due to the soaring Covid-19 cases in Yogyakarta. Even hospitals throughout the city of Yogyakarta did not give permits to Covid-19 patients. Covid-19 patients OTG and ODP have increased very quickly, even reaching four thousand. The Covid-19 Islamic boarding school was initiated by the Medical Team and Director of the PKU Muhammadiyah Yogyakarta Hospital, which is located at PKU Muhammadiyah Yogyakarta and Aisiyah University, Yogyakarta City.

The Covid-19 Islamic Boarding School uses the complete self-isolation approach model at the Covid-19 Islamic Boarding School. There are two psychosocial and neurospiritual aspects: to improve and heal Covid-19 patients by increasing faith and immunity. Neurospirituality works on the spiritual improvement of Covid-19 patients supported by obligatory prayers in congregation, voluntary fasting, sunnah prayers, tadarus al-Qur'an. These can help in increasing the power of spiritual faith. The development of social relations with psychosocial support help Covid-19 patients to avoid stress and increase immunity. Therefore, this research has implications for alternative models of Covid-19 prevention, both from physical health and spiritual health aspects such as faith. The research contributes to increasing knowledge of social development and religious behavior during the Covid-19 period.

The researcher recommends the next study to follow up this research regarding the complete isolation model of the al-Qur'an perspective, and

47 Fatma Ozlem Ozturk and Sultan Ayaz-Alkaya, 'Internet Addiction and Psychosocial Problems among Adolescents during the COVID-19 Pandemic: A CrossSectional Study', Archives of Psychiatric Nursing, 35.6 (2021), 595-601 <https://doi.org/10.1016/j.apnu.2021.08.007>. 
social behavior related to religious behavior in neurospritual and psychosocial perspectives during the Covid-19 period.

\section{References}

\section{Journals}

Alexander, Rebecca, Oriana R. Aragón, Jamila Bookwala, Nicolas Cherbuin, Justine M. Gatt, Ian J. Kahrilas, and others, 'The Neuroscience of Positive Emotions and Affect: Implications for Cultivating Happiness and Wellbeing', Neuroscience and Biobehavioral Reviews, 121 (2021), 220-49 $<$ https://doi.org/10.1016/j.neubiorev.202 $0.12 .002>$

Arifin, Tajul, Neni Nuraeni, Didi Mashudi, and Encang Saefudin, 'Proteksi Diri Saat Pandemi COVID-19 Berdasarkan Hadits Shahih', Living Islam: Journal of Islamic Discourses, $\quad 1.2 \quad$ (2020), $\quad 1-15$ <http://digilib.uinsgd.ac.id/30833/>

Barabas, Amanda J., Stephanie R. Dijak, Jane F. Yatcilla, Danielle N. Walker, and Brianna N. Gaskill, 'Modulating Captive Mammalian Social Behavior: A Scoping Review on Olfactory Treatments', Applied Animal Behaviour Science, 244.July (2021), 105489 $<$ https://doi.org/10.1016/j.applanim.2021. 105489>

Cunningham, Chinazo O., Laila Khalid, Yuting Deng, Kristine Torres-Lockhart, Mariya Masyukova, Shenell Thomas, and others, 'A Comparison of Office-Based Buprenorphine Treatment Outcomes in Bronx Community Clinics before versus during the COVID-19 Pandemic', Journal of Substance Abuse Treatment, August, 2021, 108641

<https://doi.org/10.1016/j.jsat.2021.10864 $1>$

Fazekas, Csilla Lea, Manon Bellardie, Bibiána Török, Eszter Sipos, Blanka Tóth, Mária Baranyi, and others, 'Pharmacogenetic Excitation of the Median Raphe Region Affects Social and Depressive-like Behavior and Core Body Temperature in Male Mice', Life Sciences, 286.2 (2021), 1-10 $<$ https://doi.org/10.1016/j.lfs.2021.12003 $7>$
Hopkinson, Jane B., 'The Psychosocial Components of Multimodal Interventions Offered to People with Cancer Cachexia: A Scoping Review', Asia-Pacific Journal of Oncology Nursing, 8.5 (2021), 450-61 $<$ https://doi.org/10.4103/apjon.apjon219>

Hyo, Yukiyoshi, Shigeharu Fujieda, Atsushi Matsubara, Kazuhiko Takeuchi, Motofumi Ohki, Takeshi Shimizu, and others, 'Survey of Nebulizer Therapy for Nasal Inflammatory Diseases in Japan before and during the COVID-19 Pandemic', Auris Nasus Larynx, 8.xxxx (2021), 1-10 $<$ https://doi.org/10.1016/j.anl.2021.11.00 $7>$

Ickert, Carla, Rachel Stefaniuk, and James Leask, 'Experiences of Long-Term Care and Supportive Living Residents and Families during the COVID-19 Pandemic: "It's a Lot Different for Us than It Is for the Average Joe”", Geriatric Nursing, 42.6 (2021), 1547-55 $<$ https://doi.org/10.1016/j.gerinurse.2021. $10.012>$

Jailani, Mohammad, Suyadi, and Dedi Djubaedi, 'Menelusuri Jejak Otak dan 'Aql dalam AlQur'an Perspektif Neurosains dan Pendidikan Islam di Era Pandemi COVID19', Tadris: Jurnal Pendidikan Islam, 16.1 (2021), 1-19 <https://doi.org/10.19105/tjpi.v16i1.4347 $>$

Javed, Afzal, Cheng Lee, Hazli Zakaria, Robert D. Buenaventura, Marcelo Cetkovich-Bakmas, Kalil Duailibi, and others, 'Reducing the Stigma of Mental Health Disorders with a Focus on Low- and Middle-Income Countries', Asian Journal of Psychiatry, 58.December $2020 \quad$ (2021), 102601 $<$ https://doi.org/10.1016/j.ajp.2021.10260 $1>$

Jeste, Dilip V, Michael L Thomas, Jinyuan Liu, Rebecca E Daly, Xin M Tu, Emily B H Treichler, and others, 'Is Spirituality a Component of Wisdom? Study of 1,786 Adults Using Expanded San Diego Wisdom Scale (Jeste-Thomas Wisdom Index)', Journal of Psychiatric Research, 132.9 (2021), 174-81 <https://doi.org/https://doi.org/10.1016 
/j.jpsychires.2020.09.033>

Johnstone, Brick, Daniel Cohen, and Andrew Dennison, 'The Integration of Sensations and Mental Experiences into a Unified Experience: A Neuropsychological Model for the "Sense of Self", Neuropsychologia, 159.June

$<$ https://doi.org/10.1016/j.neuropsycholo gia.2021.107939>

Kotkowski, Radoslaw, and Michal Polasik, 'COVID-19 Pandemic Increases the Divide between Cash and Cashless Payment Users in Europe', Economics Letters, 209.2 (2021), 110139

$<$ https://doi.org/10.1016/j.econlet.2021.1 10139>

Latikka, Rita, Aki Koivula, Reetta Oksa, Nina Savela, and Atte Oksanen, Loneliness and Psychological Distress before and during the COVID-19 Pandemic: Relationships with Social Media Identity Bubbles, Social Science \& Medicine (Elsevier Ltd, 2021) <https://doi.org/10.1016/j.socscimed.202 $1.114674>$

Matracchi, Pietro, and Ali Sadeghi habibabad, "Prioritizing the Effect of "Light" in the Religious Places and Environments with an Emphasis on the Sense of Spirituality', Ain Shams Engineering Joumal, 13.1 (2021), 101514 $<$ https://doi.org/10.1016/j.asej.2021.05.02 $8>$

Muscatell, Keely A., and Tristen K. Inagaki, 'Beyond Social Withdrawal: New Perspectives on the Effects of Inflammation on Social Behavior', Brain, Behavior, \& Immunity - Health, 16.July (2021), 100302 $<$ https://doi.org/10.1016/j.bbih.2021.1003 $02>$

Nadiah, Syifa, Nadia Aulia Nadhirah, and Irfan Fahriza, 'Hubungan Faktor Perkembangan Psikososial Dengan Identitas Vokasional Pada Remaja Akhir', Quanta, 5.1 (2021), $21-$ 29 <https://doi.org/10.22460/q.v1i1p1$10.497>$

Nagy, Eszter, Maria Infantino, Nicola Bizzaro, Hristina Andreeva, Hetty J. Bontkes, Xavier Bossuyt, and others, 'The Impact of the COVID-19 Pandemic on Autoimmune
Diagnostics in Europe: A Lesson to Be Learned', Autoimmunity Reviews, 20.August (2021)

$<$ https://doi.org/10.1016/j.autrev.2021.10 2985>

Ozturk, Fatma Ozlem, and Sultan Ayaz-Alkaya, 'Internet Addiction and Psychosocial Problems among Adolescents during the COVID-19 Pandemic: A Cross-Sectional Study', Archives of Psychiatric Nursing, 35.6 (2021), 595-601 $<$ https://doi.org/10.1016/j.apnu.2021.08.0 07>

Pacheco, Emily Marie, Iwona Bisaga, Rina Suryani Oktari, Priti Parikh, and Helene Joffe, 'Integrating Psychosocial and WASH School Interventions to Build Disaster Resilience', International Journal of Disaster Risk Reduction, 65.August (2021), 102520 $<$ https://doi.org/10.1016/j.ijdrr.2021.1025 $20>$

Palanca-Castan, Nicolas, Beatriz Sánchez Tajadura, and Rodrigo Cofré, 'Towards an Interdisciplinary Framework about Intelligence', Heliyon, 7.2 (2021), e06268 $<$ https://doi.org/10.1016/j.heliyon.2021.e 06268>

Renov, Veronica, Lauren Risser, Rachel Berger, Tammy Hurley, Andrés Villaveces, Sarah DeGue, and others, 'The Impact of the COVID-19 Pandemic on Child Protective Services Caseworkers and Administrators', Child Abuse \& Neglect, 3.August (2021), 105431

$<$ https://doi.org/10.1016/j.chiabu.2021.10 $5431>$

Dos Santos, Rafael Guimarães, and Jaime Eduardo Cecilio Hallak, 'Ayahuasca, an Ancient Substance with Traditional and Contemporary Use in Neuropsychiatry and Neuroscience', Epilepsy \& Behavior, 121 (2021), 106300 <https://doi.org/https://doi.org/10.1016 /j.yebeh.2019.04.053>

Schwertner, Adam, John McMenamy, and David M. Naeger, 'Radiology Imaging Volume Changes During Discrete COVID-19 Pandemic Waves: Implications for the Delta Variant of Coronavirus and Future 
Pandemics', Journal of the American College of Radiology, 3.December (2021), 20-28 $<$ https://doi.org/10.1016/j.jacr.2021.09.04 $5>$

Smith, Meghan B., Jennifer K. Blakemore, Jacqueline R. Ho, and James A. Grifo, 'Making It (Net)Work: A Social Network Analysis of "Fertility" in Twitter before and during the COVID-19 Pandemic', Fors Reports, $\quad 2.4 \quad$ (2021), 472-78 $<$ https://doi.org/10.1016/j.xfre.2021.08.00 $5>$

Strojny, Julia, Gregor Domes, Urs Fischbacher, and Bernadette von Dawans, 'The Modulation of Social Behavior and Empathy via Oral Contraceptives and Female Sex Hormones', Psychoneuroendocrinology, 131.December 2020 (2021), 105250 $<$ https://doi.org/10.1016/j.psyneuen.2021. 105250>

Sugiyono, Metode Penelitian Kuantitatif Kualitatif dan R※D, 1st edn (Bandung: Alfabeta, 2017)

Suyadi, Zalik Nuryana, and Niki Alma Febriana Fauzi, 'The Fiqh of Disaster: The Mitigation of Covid-19 in the Perspective of Islamic Education-Neuroscience', International Journal of Disaster Risk Reduction, 51.2 (2020), 101848

$<$ https://doi.org/10.1016/j.ijdrr.2020.1018 $48>$

Suyadi, and Hendro Widodo, 'Millennialization of Islamic Education Based on Neuroscience in The Third Generation University in Yogyakarta Indonesia', QIJIS: Qudus International Journal of Islamic Studies, 7.1 (2019), 173-202 <https://doi.org/DOI : 10.21043/qiijs.v7i1.4922>

Vira, Emily G., and Therése Skoog, 'Swedish Middle School Students' Psychosocial WellBeing during the COVID-19 Pandemic: A Longitudinal Study', SSM - Population Health, 16.August (2021), 100942 $<$ https://doi.org/10.1016/j.ssmph.2021.10 0942>
Voncken, Marisol J., Corine Dijk, Felix Stöhr, Isabella J.M. Niesten, Koen Schruers, and Kim P.C. Kuypers, 'The Effect of Intranasally Administered Oxytocin on Observed Social Behavior in Social Anxiety Disorder', European Neuropsychopharmacology, $53.3 \quad$ (2021), 25-33 $<$ https://doi.org/10.1016/j.euroneuro.202 $1.07 .005>$

Weiner-Light, Sophia, Katherine P Rankin, Serggio Lanata, Katherine L Possin, Daniel Dohan, and Alissa Bernstein Sideman, 'The Role of Spirituality in Conceptualizations of Health Maintenance and Healthy Aging Among Latin American Immigrants', The American Journal of Geriatric Psychiatry, 29.11 (2021), 1079-88 <https://doi.org/https://doi.org/10.1016 /j.jagp.2021.04.017>

Zhang, Zhong, Yang Zhou, Lanfang Han, Xiaoyu Guo, Zihao Wu, Jingyun Fang, and others, 'Impacts of COVID-19 Pandemic on the Aquatic Environment Associated with Disinfection Byproducts and Pharmaceuticals', Science of the Total Environment, 2.xxxx (2021), 151409 <https://doi.org/10.1016/j.scitotenv.2021. $151409>$

\section{Interviews}

Taufiurrahman, (Leader of the Muhammadiyah Covid-19 Islamic Boarding School) Interview, \{Monday, 21 February 2021

Heru, (Pasien Covid-19) Interview, \{Monday, 21 February 2021\}.

Wawali, (Pasien Covid-19 OTG\} Interview, \{Monday, 21 February 2021\}

Sigit, (Leader MCCC Muhammadiyah Yogyakarta) Interview, \{Monday, 21 February $2021\}$. 
